\title{
Variation of Essential Oil Yield in Albanian Vitex Agnus Castus L. Fruits Relating Geographic Position
}

\author{
Evelina Hasa $^{* *}$, Sonila Duka ${ }^{2}$, Ervis Lika ${ }^{3}$, Sidita Mance ${ }^{4}$ \\ 1,2,4 Tirana University, Faculty of Natural Sciences, Chemistry Department; \\ ${ }^{2}$ Tirana University, Faculty of Natural Sciences, Chemistry Department; \\ ${ }^{3}$ Noval Laboratory shpk, Koxhas, Maminas, Durres;
}

\begin{abstract}
This study investigates variation of Albanian Vitex Agnus Castus L. essential oil yield relating geographic position. Twelve samples were taken for this study. Sampling was done on different locations, from north to south Albania, during October, 2017 the main harvesting period, when the seed is fully matured. At each location fruits were collected randomly, from a large number of plants, representing the population of the sampling station. Samples were comminuted before extraction, and essential oils were obtained by hydro-distillation method, using a Clevenger-type apparatus. The mean oil yield obtained from all samples was $0.49 \%$. For different locations, it varies from $0.74 \%$ Gjader/V5 \& Vau i Dejes/V3 to $0.15 \%$ Seman/V7. A considerable variation is seen between different locations of Albanian Vitex Agnus Castus L. High yielding populations are located mostly in north and north-west of Albania, mostly in the same environment such as near the sea or near a river bed. Samples taken in west and south west, show a moderate yield percentage, Seman/V7 station show the lowest yield percentage $0.15 \%$, due to a more inland location comparing to other stations.
\end{abstract}

Key words: extraction; hydro-distillation; Lamiaceae; seeds; vitex

\section{Introduction}

Vitex agnus-castus L. (VAC) is an aromatic, deciduous, and very decorative shrub, which formerly was classified in the family of Verbenaceae, but now the phylogenetic classification assorts it in the Lamiaceae (Aissaoui, 2010, Meena et al., 2010). Albanian local names for this plant are konopica, kopër mace, lule shingjergjit, lule e qenit, maraqe. VAC flowers during June - July and grows in areas where the Mediterranean climate is dominant, rather rocky places, wetlands such as stream banks and valleys (Cossuta et al., 2008), $\mathrm{t}$ is found in saturated soils, with a preference for basic to slightly acid $\mathrm{pH}$. Soil structure is of various types of aluviones, more frequently the fine one (clay) and soils with good water reserves, sites with a 


\section{$5^{\text {th }}$ International Conference On Applied Research In SCIENCE, TECHNOLOGY \& KNOWLEDGE}

26-28 February, 2021

Amsterdam, Netherlands

favourable water balance (GIZ, 2013), Leaves are characterized by aromatic flavour, which repels mosquitoes, while spikes are generally close to or at the ends of branches and they are weakly aromatic, varying in colour from purple to light purple and seed is oval to almost globular, with a diameter of up to $5 \mathrm{~mm}$, (Cossuta et al., 2008, Sorensen \& Katsiotis, 1999), VAC, is an important natural source of food and medicine products used all around the world (Meena et al., 2010), such as in Italy, Iran, Greece, and Egypt for over 2500 years, mainly to treat the gynecologic disorder (Roemheld-Hamm, 2005). The word "cactus" has been used for centuries to remark the meaning or purity associated with this plant (Eliana, 2020). Medicinal wild plants have been considered worldwide and for centuries valuable in the treatment of different diseases, due to their ease of use and improved cost-effectiveness compared to chemical remedies obtained from synthesis (Yeung et al., 2020). Fruits of VAC tree have been traditionally used in the treatment of women complaints, including menstrual disorders (amenorrhea and dysmenorrhea), premenstrual dysphoric disorder, corpus luteum insufficiency, hyperprolactinemia, infertility, acne, menopause, disrupted lactation, cyclic breast pain, cyclical mastalgia, and inflammatory conditions, diarrhea, and flatulence (Ono et al., 2008, Costa et al., 2007, Dugoua et al., 2008). Hydro-distillation of VAC fruits yields a pale-yellow to yellow essential oil with agreeable, interesting, somewhat peculiar top-note, reminding one of cannabis and eucalyptus. After a few minutes, it revealed an aromatic floral, warm but fresh, somewhat peppery, sweet, spicy fragrance with lemon-like, woody undertones (Sorensen \& Katsiotis, 1999). The fruits, as well as leaves and flowers, contain essential oil, which varies in content and composition relating to geographical position (Sorensen \& Katsiotis, 1999), Zwaving \& Bos, 1996). In this study, we will be reporting the results of an investigation of Vitex agnus castus L. fruits oil content, collected in different sampling stations along the Albanian coast and not only.

\section{Materials and methods}

\subsection{Plant material}

Twelve samples were taken for this study. Sampling was done on different locations, from north to south Albania. Sampling points were located in different geographic locations such as, Shiroke/V1, Ura e Bunes/V2, Vau I Dejes/V3, Torovic/V4), Gjader/V5, Ura e Milotit/V6, Seman/V7, Pishpore/V8, Novosel/V9, Radhime/V10, Himare/V11, Qeparo/V12. Samples were taken in two consecutive days, during October, 2017 the main harvesting period, when the seed is fully matured. Sampling site is presented in Figure 1. Part of the plant chosen to be analyzed were aerial parts (fruit). One representative sample per location were picked. At each location fruits were collected randomly, from a large number of plants, representing the population of the sampling station. Samples were collected by hand, taking into account "Good collection practice of medical and aromatic plants in nature" and were placed in airy places, in shade to get fully dried at room temperature. 


\section{$5^{\text {th }}$ International Conference On Applied Research In SCIENCE, TECHNOLOGY \& KNOWLEDGE}

26-28 February, 2021 Amsterdam, Netherlands

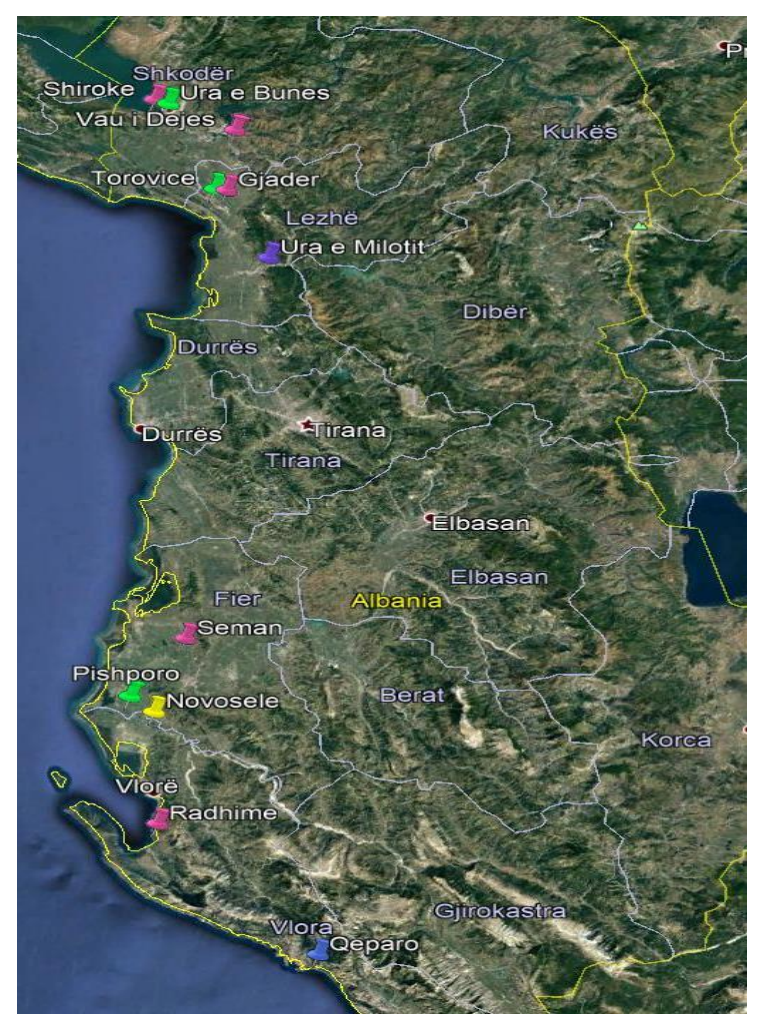

Figure 1. Sampling site and the sampling point

\subsection{Oil extraction}

Dry mature fruits were cleaned from impurities and dust. Samples were comminuted before extraction, until all particles pass through a $0.8 \mathrm{~mm}$ sieve. Immediately after the comminution, hydro distillation process commenced. Hydro distillation, were carried out for all samples, using a Clevenger-type apparatus. The quantity of sample used is $30 \mathrm{~g}$ immersed in $510 \mathrm{ml}$ water and boiled using distillation flask heater for 3 hours, at boiling point temperature. The plant/liquid ratio used for this study was $1: 17$ ( $\mathrm{g}: \mathrm{ml})$. The obtained essential oils were dried over anhydrous sodium sulphate and stored at $4-5{ }^{\circ} \mathrm{C}$ for further analysis. 


\section{$5^{\text {th }}$ International Conference On Applied Research In SCIENCE, TECHNOLOGY \& KNOWLEDGE}

26-28 February, 2021

Amsterdam, Netherlands

\section{Results and discussion}

\subsection{Yield percentage of Essential Oils}

Essential oil content evaluation, in this study is done relating on one factor: geographic position and, the results for each sample are shown in Table 1 . The mean oil yield obtained was 0.49 $\%$. In different locations varies from $0.15 \%$ to $0.74 \%$, which is a considerable variation. According to Janina. M.S et al., 1999, who studied Cretan (Greek) VAC fruits, yield percentage range, for this population was from $0.15 \%$ to $1 \%$.

Table 1: Oil extract percentage for Vitex agnus castus $L$. fruit in different geographic locations

\begin{tabular}{l|c|c}
\hline Place of sampling & \multicolumn{1}{c}{$\begin{array}{c}\text { Sample } \\
\text { code }\end{array}$} & $\begin{array}{c}\text { Oil extract } \\
\%\end{array}$ \\
\hline Shiroke & V1 & 0.52 \\
\hline Ura e Bunes & V2 & 0.43 \\
\hline Vau I Dejes & V3 & 0.74 \\
\hline Torovic & V4 & 0.60 \\
\hline Gjader & V5 & 0.74 \\
\hline Ura e Milotit & V6 & 0.68 \\
\hline Seman & V7 & 0.15 \\
\hline Pishpore & V8 & 0.54 \\
\hline Novosel & V9 & 0.44 \\
\hline Radhime & V10 & 0.44 \\
\hline Himare & V11 & 0.43 \\
\hline Qeparo & V12 & 0.54 \\
\hline
\end{tabular}

Figure 2. Oil extract percentage for Vitex agnus castus L. fruit in different geographic locations

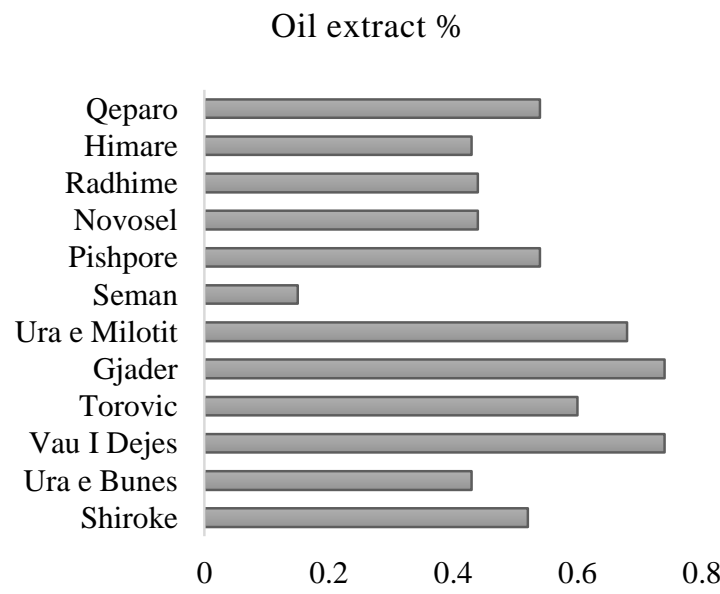

It is stated that in composition, qualitative terms, Cretan essential oil is similar to the Mediterranean region. Results of our study in terms of yield percentage seems quite close to the Janina. M.S et al., 1999 study, taking into account the geographical proximity and, the Mediterranean climate that characterizes both regions. In this study, yield percentage referring to geographic position, the same year, and same harvesting period, varies from $0.74 \%$ Gjader/V5 / Vau i Dejes/V3 > $0.68 \%$ Ura e Milotit/V6 > $0.60 \%$ Torovic/V4>0.54\%Pishpore/V8/Qeparo/V1> 0.52\% Shiroke/V1 > 0.44\% Radhime/V10/ Novosel/V9 > 0.43\% Ura e Bunes/V2/ Himare/V11 > 0.39\% > 0.15\% Seman/V7. Essential oil yield shows interesting differences for plants cropped in different location (Table 1). In this study high yielding populations are located mostly in north and north-west of Albania, mostly in the same environment like near the sea or near a river bed such as Gjader/V5, Vau I Dejes/V3, Ura e Milotit/V6 or Torovic/V4 (Figure 3). But there are populations cropped in north such as Shiroke/V1 or Ura e Bunes/V2, that shows a moderate yield percentage referring to the range $0.15 \%$ to $0.74 \%$ and lower, comparing to the one obtained in samples such as Gjader/V5. Samples taken in west and south - west (Figure 4), show a moderate yield percentage, Samples taken in west and south - west, show a moderate yield percentage probably due to the fact that is more inland comparing to other stations. 
Figure 3. Oil extract percentage for Vitex agnus castus L. fruit in north and north-west Albania
Figure 4. Oil extract percentage for Vitex Agnus Castus L. fruit in west and south-west Albania

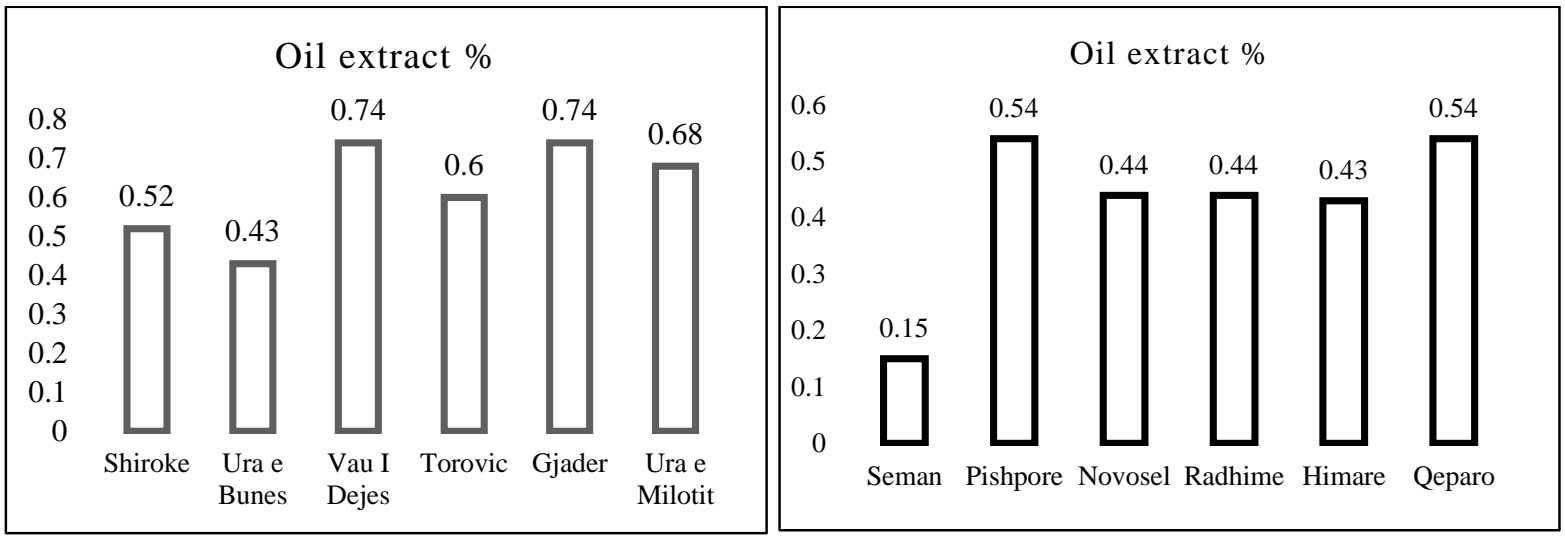

\section{Conclusions}

From the above results it can be concluded:

$\checkmark$ there are significant variations in essential oil yields percentage, referring geographic position, same year, and same harvesting period

$\checkmark$ Vitex agnus castus L. samples essential oil varies, from $0.15 \%$, Seman/V7 to $0.74 \%$, Gjader/V5 and Vau I Dejes/V3.

$\checkmark$ The biggest difference was found between Gjader/V5/Vau I Dejes/V3 and Seman/V7 locations. Gjader is in north-west and Seman in west of Albania.

$\checkmark$ Results show that this pattern is the same for mostly of the samples.

$\checkmark$ It was interesting to find that yield percentage of essential oil, obtained in samples located in south Albania, such as Radhime/V10 or Himare/V11, was in moderate percentage compared to north or north-west.

Different factors can contribute to these results because the fulfillment of certain basis conditions for medicinal and aromatic plants growth and normal development are required. Among the most important factors are: climate, soil, their cultivation, age etc (Florina, 2014). Soil composition changes the nature and amount of plant active substances, which it is also associated with the growth and spread of plant species. Permeability, moisture, capillary as well as porosity affect soil fertility and aromatic plants yield, productivity (Akademia e Shkencës, 1988, 1992, 1996, 2000).

\section{References}

[1] Aissaoui, H., (2010), "Recherche et détermination structurale des metabolites secondaires de type flavonique d'une espèce de la famille des Verbenacées," In: Departement de chimie. Constantine: Universite mentouri constantine, faculte des $\underline{\text { sciences exactes }}$ 


\section{$5^{\text {th }}$ International Conference On Applied Research In SCIENCE, TECHNOLOGY \& KNOWLEDGE}

26-28 February, 2021

Amsterdam, Netherlands

[2] Meena, A.K., Singh, U., Yadav, A., Singh. B., (2010), "Pharmacological and phytochemical evidences for the extracts from plants of the genus Vitex-a review," Int. Journal. Pharm. Clin. Res., Vol. 2(1), pp. 01-09.

[3] Cossuta. D, Simandi. B, Vagi. E, Hohmann. J, Prechl. A, Lemberkovics. E, Kery. A, Keve. T, (2008), "Supercritical fluid extraction of Vitex agnus castus fruit," Journal Supercrit. Fluid, vol. 47, pp. 188-194.

[4] GIZ, (2013), "Albania's natural heritage of medicinal and aromatic plants (Monograph description of 40 medicinal and aromatic plant species and their importance for the livelihoods of mountain communities in Albania)", Tirana.

[5] Sorensen, J.M., Katsiotis, S.T., (1999), "Variation in essential oil yield and composition of Cretan Vitex agnus- castus L. fruits," Journal Essent. Oil Res, vol. 66, pp. 245-250.

[6] Roemheld-Hamm, B, (2005), "Chasteberry", Am. Fam. Physician, Vol. 72(5), pp. $\underline{821-824 .}$

[7] Eliana B. Souto, Alessandra. D, Amirhossein. N, Massimo .L, Massimo .Z, Selma B. Souto, Amelia M. Silva, Patricia. S, Ettore. N and Antonello. S, (2020), "Vitex agnuscastus L.: Main

Features and Nutraceutical Perspectives," Forests journal, vol. 11, pp.1-16.

[8] Yeung, A.W.K.; Heinrich, M.; Kijjoa, A.; Tzvetkov, N.T.; Atanasov, A.G. (2020), "The ethnopharmacological literature: An analysis of the scientific landscape. J. Ethnopharmacol", JEP 112414.

[9] Ono M, Yamasaki T, Konoshita M, Ikeda T, Okawa M, Kinjo J, et al. (2008), "Five new diterpenoids, viteagnusins A-E, from the fruit of Vitex agnus-castus," Chem Pharm Bulletin, Vol. 56, pp. 1621-1624.

[10] Costa MR, Ribeiro CG, Santos-Filho SD, Neves RF, Fonseca AS, Bernardo-Filho M, et al, 2007), "An aqueous extract of Vitex agnus castus alters the labeling of blood constituents with technetium-99m," Braz Arch, Biol Technol, vol. 50, pp.183-88.

[11] Dugoua, JJ., Seely, D., Perri, D., Koren, G., Mills, E., (2008), "Safety and efficacy of chastetree (Vitex agnus-castus) during pregnancy and lactation," Can Journal, Clin Pharmacol, vol. 15(1):74-9.

[12] Zwaving, JH., Bos, R., (1996), "Composition of the essential fruit oil of Vitex agnuscastus", Planta Med, vol. 62(1):83-4.

[13] Florina, P., (2014), "Vlerësimi ekonomik dhe ekologjik i bimëve mjekësore dhe aromatike të shqipërisë në funksion të zhvillimit të ekonomisë rurale," 
[14] Akademia e Shkencës, "Flora e Shqipërisë, Volumi I, II, III, IV, Tiranë, 1988, 1992, 1996, 2000. 